\title{
The Ambivalence toward Teaching in the Early Years of the American Philosophical Association
}

\author{
JAMES CAMPBELL \\ The University of Toledo
}

Philosophers who are particularly dedicated to the teaching aspects of their careers often see themselves as being in the minority within the contemporary profession. The profession, it seems to them, is interested in the ongoing flow of philosophical ideas, in the historical development of this topic or the current literature on that; but this interest in matters of philosophical content is seldom matched, they believe, by an equal devotion to matters pedagogical. We recognize, of course, that at different times we all belong on different sides of this split. We, and our profession, are of two minds on the importance of teaching. Given this ambivalence, it is natural to wonder whether there ever was a time in our past when the concern with philosophy teaching was really central. To partially answer this question, we can consider the activities of the first decades of the professional associations that merged into the American Philosophical Association in 19261927. These associations-the Western Philosophical Association [WPA] (founded in Kansas City in January, 1900) and the American Philosophical Association [APA] (founded in New York City in November, 1901) ${ }^{1}$-offered to aspiring philosophers models for proceeding with their careers and guidelines for success. What was the role that philosophy teaching played in the emerging APA mindset? The answer-as might be guessed-is an ambiguous one: while there were occasional moments when pedagogy took center-stage, there was no golden age for philosophy teachers to be found in the early years of the APA. 


\section{Philosophy before the APA}

The background to the founding of the philosophical associations can be seen as a potentially favorable one for a focus upon teaching. The philosophers who were supportive of these professional groups were rebelling in part against the felt inadequacies of their own undergraduate educations. These philosophers, most of whom we would identify as Idealists of some sort, saw in the older Common Sense Realism of their studies a kind of watered-down and safe orthodoxy: instead of "real" philosophical questioning, these philosophers felt that they had been offered a kind of apologetics for religious and political conservatism. The "oldtime" colleges in which they had been educated generally offered philosophy as a senior-year course taught by the college president, who was invariably an ordained minister; and, in this context, the philosophy with which they were presented was seldom the living product of an unfettered, speculating mind. The founders of the APA wanted something better. ${ }^{2}$

One of the earliest and sharpest published criticisms of this situation was from the pen of the philosopher-psychologist, Granville Stanley Hall. ${ }^{3}$ In January of 1879 , he reported on his recent examination of the catalogues of "nearly 300 non-Catholic colleges in the United States." In the course of his report, Hall summarized the contemporary philosophical scene: "In nearly all these institutions certain studies, aesthetical, logical, historical, most commonly ethical, most rarely psychological, are roughly classed as philosophy and taught during the last year almost invariably by the president." His evaluation of the quality of this philosophical work is almost uniformly grim. In most of these cases, Hall writes, "the instruction given in philosophy is rudimentary and mediaeval. . . Many teachers of philosophy have no training in their department [i.e., discipline] save such as has been obtained in theological seminaries, and their pupils are made far more familiar with the points of difference in the theology of Parks, Fairchilds, Hodges, and the like, than with Plato, Leibnitz or Kant." In this account, there are very few bright spots to be found: "there are less than half a dozen colleges or universities in the United States where metaphysical thought is entirely freed from reference to theological formulae." In the vast majority of cases, however, Hall points to the primacy of theological orthodoxy: "these institutions unite in impressing upon their students the lesson that there is an abyss of scepticism and materialism into which, as the greatest of all intellectual disasters, those who cease to believe in the Scriptures as interpreted according to the canons of orthodox criticism, are sure to be plunged." ${ }^{4}$ In line 
with the criticisms of Hall, there was a growing feeling that philosophy could contribute more to the academic life of the colleges, and to the education of students, if it were freed from these restraints. George A. Coe of Northwestern University wrote in 1892 that a number of factors, including the nature and aims of the old-time college and "the traditional notion that the chair of "mental and moral philosophy' is a natural appendage of the office of president, and that the chief qualifications for this office have been clerical ordination and financial and executive ability" have contributed to produce "the dreary fudge that has been handed down under the name of philosophy." 5

Part of the solution to philosophy's felt problems was to be found in the development of the new research universities. It was within these institutions-like Johns Hopkins University (founded in 1876), Clark University (1889), and the University of Chicago (1892) 6 - that a new conception of education, nourished in many cases by faculty and administrators who had studied in German universities, was able to flourish. The new university was a place of research and discovery, where "learning" meant not drill and recitation of age-old knowledge, but explorations of the unfamiliar. In 1890, Josiah Royce, who had studied in Germany in 1875-1876 and later earned one of the first doctorates from Hopkins in 1878, described that institution as follows: "The Johns Hopkins University was the first academic institution [in America] to announce that its principal purpose would be the training of advanced students, who already held the Bachelor's degree, or some equivalent degree, and their preparation for higher work in research and in teaching." ${ }^{\prime 7}$ In these proliferating graduate schools, however, teaching-especially the teaching of undergraduatesdid not always fair very well. In 1899, for example, President James Burrill Angell of the University of Michigan wrote that as he surveyed these developing American graduate schools he saw that "[i]n these are some learned, conscientious, and inspiring professors who impart as good instruction as can be obtained in any European university. The fact that most of them are handicapped by the necessity of giving instruction to undergraduates, of course, seriously interferes with the attainment of the best results." ${ }^{8}$ While we may find this move away from a focus upon undergraduate education problematic, the general contemporary impression of this shift in institutional emphasis seems to have been positive. In 1894, Hall had described the liberation that professors experienced in graduate-level teaching as follows: "To be thus emancipated from routine teaching, marks, examinations, and other forms of tuition-learning, and to be left with ample 
opportunity to do his best work, was a boon as new as it will forever be welcome to every professor who has ability and inclination for higher scientific work."9 Similarly, President William Rainey Harper of the University of Chicago noted in 1903 that "[t]he professor of former times had little or no opportunity for any work aside from his teaching. . . [T]he spirit of research, once hardly recognized in our higher educational work, is now the controlling spirit; and opportunities for its cultivation wait on every side." ${ }^{10}$ America's philosophers thus had wanted philosophical "progress": a move away from the safe and stagnant instruction that they had received from the minister president of the old-time college. This progress could have entailed a more direct concern with the educational experiences of undergraduates, with teaching that prepared them for life in the new century. Instead, it came to be seen primarily in terms of the research and professional interests of professors.

\section{The Emergence of the Professional Philosopher}

It was in this context, largely unfavorable to interest in the undergraduate classroom, that the philosophical associations were born. The "progress" of the discipline of philosophy was the goal; and, while the discipline had not yet fully divorced itself from the psychological, sociological, and related approaches of the other developing disciplines, philosophy's vision was progressively narrowing. The expertise that these philosophers sought was in advancing their professional interactions, and effective pedagogy was considered-if at all-as a natural outcome of this expertise.

We can approach the mind-set of the founders through an examination of the first APA presidential address. In this address, given 31 March 1902, James Edwin Creighton of Cornell expounded on what he took to be "The Purposes of a Philosophical Association." Creighton writes tellingly that, "it is in promoting and facilitating the interchange of ideas between the philosophical workers of the present day, who are scattered throughout this part of the country, that the Association finds its main function." The APA would thus improve the future of philosophy in America by facilitating the cooperation of philosophical professionals. Creighton writes that "the insufficiency of the isolated individual and the consequent necessity of cooperation have not been so clearly realized by philosophers as by workers in almost every other department of knowledge." Moreover, this has been so even though "philosophy, of all species of scientific inquiry, is that which demands, in order to be fruitfully prosecuted, the closest 
and most intimate intellectual relations between a number of minds." Creighton continues that "the data of the philosopher are so complex and many-sided that, working by himself, he is certain to fail to take account or properly estimate some facts of importance. . . . [N]o single individual can look, as it were, in all directions at once." The philosophers' need for others to challenge and supplement their work is best satisfied by direct personal interaction. As he writes, "when objections and opposing views are backed by the immediate presence of one's neighbor, they cannot easily be ignored"; and this kind of cooperative forum was what the APA would provide. ${ }^{11}$

Although Creighton recognized that almost all of those "philosophical workers" had careers teaching philosophy in colleges and universities, he rejected an interest on the part of the association in teaching, which he disparages as "die zeitraubende und kraftabsorbirende academische Lehrthätigkeit." ${ }^{2}$ To get a fuller sense of Creighton's aversion to matters pedagogical, we can quote him at length:

[I]t would be a mistake to make the discussion of methods of teaching philosophy a coordinate purpose, or even to introduce papers on this subject in the programme of the meetings. Even if the membership of the Association were composed wholly of teachers of philosophy, which will never, I hope, be the case, the meetings should not, it seems to me, be occupied with the consideration of such secondary and subordinate topics. . . . [T] he discussion of methods of teaching philosophy is in itself rather a stupid way of wasting time. ... [E]ven in our capacity as teachers it is courage and inspiration to attack problems for ourselves, to go to first-hand sources and so actually discover by our own efforts what we teach to students, that is the one thing needful. . . The important thing is that one shall have something of one's own to tell, something in the importance of which one thoroughly believes, and which has cost real effort to discover. It seems to me, then, that it will be an advantage in every way for the members of this Association to forget, so far as possible, their profession during the days of meeting, and to come together simply as human beings interested in philosophical investigation and scholarship.

Thus, for Creighton and, presumably, the other founders who chose him as their president, the focus of the APA's efforts was not to be anywhere near the undergraduate classroom: "The main purpose which we should conscientiously set before us, it seems to $\mathrm{me}$, is to promote and encourage original investigation and publication. ... [T]his Association may do much both to inspire and direct original work. Above all, it may become an important agent in creating the atmosphere and furthering the spirit which are essential to scholarly research." ${ }^{13}$ 
The focus of the APA was thus to be upon the creation of original work; the advancement of philosophy was to take place through the cooperative efforts of scholars. Creighton maintains that a philosophical association that managed to advance philosophy in this way would go a long way toward redressing the low "standing of philosophy in the learned world as a specialized subject of inquiry." ${ }^{14}$ Philosophy was still understood by too many in academia as being what it had been: the religiously-oriented capstone on the education of a Christian gentleman. Because philosophy-in the consciousness of its external evaluators at least-was still an activity of amateurs rather than of professionals, Creighton notes, its "scientific status as a real and independent subject of investigation is tacitly or explicitly denied." 15 While this problem was serious, he was certain that he had the answer in the establishment of the APA. If philosophers wanted to achieve the respect and status that had been achieved by the other scientists, then they would need to cooperate like other scientists. Creighton believed that even among philosophers this recognition had begun to rise. While he admits that "[p]hilosophers have been slower than their fellow workers in inaugurating any movement to secure this end," 16 he maintains that with the establishment of the APA there would be the possibility of greater personal interaction and of more sustained public and cooperative work, as long as the assembled philosophers did not waste their valuable time considering the issue of philosophy teaching.

\section{The Topic of Philosophy Teaching at the Early Meetings}

In spite of the suggestion of the first APA president that philosophical associations not involve themselves with pedagogical matters, there was from the earliest years some modest level of interest in teaching in both of the associations. At the second meeting of the WPA, for example, a few months before Creighton gave his warning, President John H. MacCracken of Westminster College discussed the purposes of philosophy in the college curriculum and the approach to teaching that is most likely to attain them. He notes that the aim of mental discipline is most likely to be reached through logic, psychology and ethics; and the aim of familiarization with culture, through the history of philosophy. The further aim of leading "the student to philosophize, to raise the ultimate questions, and thus to enter upon the noblest activity of his manhood," MacCracken continues, will only be attained by courses in metaphysics that he thought were then being crowded 
out by introduction to philosophy courses. These, he thought, were all too often mistaken attempts "to furnish an encyclopaedia of philosophy" that run "the risk of disgusting the student with philosophy" because they present it "in its driest possible form." As MacCracken formulates this point, "[t]here is as much difference between such a bare outline of philosophical problems, and the works of a philosopher like Descartes or Locke, as between a brief history of the world and a good historical novel." 17

At the second meeting of the APA in December 1902, there was also a session of particular interest to philosophers as teachers. In this session, Dickinson Sergeant Miller and Josiah Royce of Harvard, President Francis L. Patton of Princeton, and William Torrey Harris of the U.S. Bureau of Education, discussed the question: "What Should be our Attitude as Teachers of Philosophy toward Religion?" Royce, for example, noted that "[r]eligion . . . is the most important business of the human being" but "among the worst managed of humanity's undertakings." The greatest contribution that the philosophy teacher could offer to improve religion, he continues, would be to bring "(a) clearness of thought about religious issues, and (b) a judicial spirit in the comparison, the historical estimate, and the formation of religious opinions." Royce also recommends that "the philosophical teacher . . . conscientiously avoid all connection with any sect or form of the visible church." 18

Returning to the WPA, we can survey briefly the sessions on philosophy teaching over the first decade or so. At its seventh meeting, two papers related to teaching were read: James Hayden Tufts, "Garman as a Teacher," and James Rowland Angell, "The Teaching of Psychology." In the former, Tufts discusses the work of Charles Edward Garman, his teacher at Amherst College, with emphases upon both his pragmatic conception of philosophy and his method of using privately-printed pamphlets to help bring contemporary issues into the philosophy classroom. ${ }^{19}$ At the ninth meeting of the WPA, as part of a general celebration of the semicentenary of the St. Louis Movement, there was a paper by Jay William Hudson that advocated adopting the approach (if not the text) of Hegel's Phänomenologie des Geistes (1807) as the most effective way of introducing students to philosophy. ${ }^{20}$ At its tenth meeting, there was a trio of papers of importance to philosophy teachers, especially those concerned with introductory-level teaching. Edgar L. Hinman discussed what he took to be the three main aims of an introductory philosophy courses: (1) to display "the unity of human culture" and offer "a breadth of vision and of sympathies much needed in our time"; 
(2) to train students "to the spirit of critical and fundamental thinking"; and (3) to give "an ordered survey of the system of the sciences" to help students integrate broad cultural ideas with "the present state of speculation in natural science." Hudson discussed an introductory course that emphasized historical events and institutions rather than the more familiar approach. This view could still manage to reach issues of "the true, the real, and the right," he thought, and it would have the added advantage of holding student interest. As he notes: "In themselves, the metaphysical problems are not likely to heighten the pulse of the average sophomore. But the conditions are changed when problems are made to emerge from absorbing social conflicts and compelling natural crises." In the third paper, Bernard C. Ewer offered a naturalistic approach to introductory philosophy, one that avoided the metaphysical emphases of the "ordinary" course and explored "the popular writings of eminent scientists," attempting to uncover "the numerous metaphysical assumptions and problems involved, and thus gradually leading up to the fundamental questions of ethics and religion." 21

This discussion of the introductory course apparently struck a sympathetic chord within the membership of the WPA, because at the next meeting Ewer, the WPA secretary, reported on the work that had been undertaken by a committee established the year before to examine "Introduction to Philosophy" courses. The committee, made up of the trio of Hudson, Hinman and Ewer, had mailed a questionnaire to fifty teachers of philosophy asking about such topics as their favored methods, texts, and so on, and received thirty-four responses. Ewer offered the following as the committee's preliminary findings: "[t]he text preferred by a majority of professors is that of Paulsen", ${ }^{22}$ there are some doubts among philosophy teachers about the utility of the course; "most [teachers] regard it as a systematic statement of philosophical problems, and rely mainly on the history of philosophy for material"; and finally, in the introductory course as it is most frequently taught, "there is a comparative neglect of the synthesizing functions of philosophy as applied to the social sciences." 23 The full report, based upon thirty-five responses to the fifty questionnaires, appeared in early 1912. In it, Hudson, the committee's chair, describes in greater detail the specifics of the responses and suggests the importance of information-gathering if individual instructors are to have the benefit of "the reflective experience of numbers of teachers." While admitting that this particular survey was "more or less off-hand," Hudson still defends its general accuracy and its overall impression that in successful philosophy 
teaching the philosophical problems must "emerge from ... the student's point of view" and the students must not see philosophy as "a thing of futility, an empty speculation." 24

At the twelfth meeting of the WPA in 1912, the overall theme was ethics; and one of the sessions was devoted to the problems of teaching ethics, especially as related to the first course. One of the speakers was again Jay William Hudson, who emphasized the important role that ethics plays in a system of education for democracy. A second speaker, Frank C. Sharp, maintained that, because of its importance "for the guidance of life," the introductory course in ethics should be free from prerequisites and limited to one semester so that it would be "accessible to the largest possible number of students." Sharp also recommended that the normal "pouring-in method" of familiarizing students with the history of ethics be replaced with "the method of discovery, in which the members of the class are given problems to work out," thus treating society as "an ethical laboratory." A more traditional emphasis was offered by Gregory D. Walcott, who defended the importance of teaching the history of ethics. He also stressed the need to inform students in the introductory ethics class about such topics as the proper method of ethics, the field of ethics as distinct from sociology, the different planes of ethical living, criteria of moral progress, and the ideal and its realization. ${ }^{25}$

Back East, some interest in teaching philosophy continued as well. The seventh meeting of the APA in 1907 lists a paper by Brother Chrysostom of Manhattan College entitled "The Teaching of the History of Philosophy",26 and the next year Frances H. Rousmaniere of Smith College considered replacing Mill's methods in introductory logic with a method she saw as more in conformity with scientific practice. ${ }^{27}$ At the twelfth meeting of the APA, George Clarke Cox of Dartmouth College reported on his recent experiences with replacing his "old methods" for teaching ethics- "teaching men ethics rather than to be ethical"-with a case-study method that attempts to engage students in what becomes "not a study of human opinions but of human conduct." 28 Three years later, at the fifteenth meeting of the APA, Bernard C. Ewer read a paper entitled "Hindrances to the Teaching of Philosophy," which considered the difficulties presented by the artificial classroom situation, the limitations on thought imposed by (ecclesiastical) authorities, and the mechanistic assumptions of a generally "scientific" atmosphere to teaching philosophy that aims at "guiding human life and . . . synthesizing facts and principles of science in a unitary view of the universe." 29 


\section{A Deeply Rooted Ambivalence}

These papers on various aspects of philosophy teaching were gleaned from the hundreds of papers offered at the meetings of the two philosophical associations over the early years of their existence. The infrequency of such papers demonstrates that pedagogical concerns-while never completely missing-were only a minor component in the professionalizing drive of American philosophy. The professional associations directed most of their energies elsewhere. The presence of the papers on the programs of the associations does demonstrate, however, the deep roots of the fundamental ambivalence of the APA toward teaching that we still experience today. On the one hand, the associations' members were philosophy teachers who faced many of the same classroom problems that we face today-what books to choose, what themes to emphasize, how to hold student interest, how to construct a philosophy curriculum, etc.- -and some of them wanted to discuss these problems with their fellow teachers at the meetings. On the other hand, the members of the associations felt themselves, just as we feel ourselves, powerfully drawn by the fascinations of philosophy; and they wanted to use their precious moments together comparing their ideas on topical matters. Their ambivalence was, as is ours, rooted in the difficulty of combining the pedagogic responsibilities of the philosophy teacher with the creative freedom of philosophical research.

This ambivalence can again be demonstrated through a consideration of the 1917 report of the APA's Committee on Discussion, ${ }^{30}$ prepared under the chairmanship of its immediate past president and strong advocate of organized efforts toward philosophical progress, Arthur Oncken Lovejoy. In a kind of preamble to its report, the committee presented what it took to be three "characteristic objects" of the APA. This report can thus be taken as a kind of policy statement of the leadership of the APA, ${ }^{31}$ reminiscent of Creighton's presidential address sixteen years before. ${ }^{32}$ The first of these three objectives was "to promote what may be called philosophical scholarship - the study of the history of speculative thought and its interaction with other phases of human culture." The committee granted that this historical work had been under-represented at recent APA meetings. The second aim of the APA was to improve teaching. "Since the membership of the Association consists in the main of teachers in colleges and universities," the report notes, "it falls within the natural province of the society to consider from time to time the pedagogical aspects of the subject-to discuss methods of effectively teaching philosophy, and the place and function of the several 
branches of it in the college curriculum." The committee continues, however, that while "occasional" focusing on the problems of teaching "might sensibly contribute to the improvement of philosophical instruction in this country," the interest of the APA with teaching should be kept "decidedly subordinate to the other two. ..." These interests were the (just-mentioned) work on the history of philosophy and the third aim of the APA, efforts to help philosophy advance. In the eyes of the majority of the committee, this task was the most important: "The Association exists chiefly for the promotion of philosophical inquiry. Its principal purpose is to assist toward the attainment of a progressively better understanding of philosophical problems themselves, by means, primarily, of a better understanding by philosophers of the results of one another's reflections." 33 The rest of the report, recommending procedures for the upcoming discussion sessions, need not detain us except to note that in the course of the debate during the business session of the 1917 meeting this preamble was, for unspecified reasons, withdrawn. ${ }^{34}$

The APA, in other words, did not assert in 1917 that philosophy teaching was a "subordinate" objective of the association. Then again, the APA did not assert that philosophy teaching was not a subordinate objective. We find ourselves, eighty-five years later, continuing this ambivalent relationship toward teaching. In the meantime, the APA has created numerous institutional focicommittees on teaching at the pre-college, two-year college and four-year college levels, the Newsletter on Teaching Philosophy, and various other committees on organizational aspects of the profession-that attempt to hold classroom issues before the eyes of the membership. At the same time, the fascination with philosophical "progress," freed from the constraints of pedagogy, remains a powerful force. We are, just as were our earlier colleagues, ambivalent toward philosophy teaching.

\section{Notes}

1. The third party to this merger, the Pacific Division of the American Philosophical Association, was formed under that name in April 1924, and formally merged with the other two divisions in 1926-1927. Up to that time, the associations were independent of each other, although their memberships somewhat overlapped.

2. The mood of the founders can be seen in the following negative commentaries on the impact of Common Sense Realism on American philosophical thinking.

R. M. Wenley (1917): "[T]he average experience of 'respectable, Christian' men in New England afforded a norm which few, if any, in the colleges at all events, dreamed of questioning. Thus, no thorough assault upon fundamental problems could 
occur and, and as a matter of fact, none did occur" (The Life and Work of George Sylvester Morris, 197).

Herbert Wallace Schneider (1946): "Philosophers, in the eighteenth-century meaning of the term, were investigators (either natural or moral); in the nineteenth century, however, there grew up a species of educator known as professors of philosophy. They were primarily teachers, and their ambition was to be orthodox, to teach the truth, i.e., to instruct their students in correct doctrine by relying on the best authors, by using systematic texts, and by inventing precise terminologies" (A History of American Philosophy, 226).

Joseph Leon Blau (1952): “The choice of Scottish 'common sense' realism for American colleges was dictated primarily by the need for a system which did not conflict with the teachings of the Protestant, chiefly Calvinist, religion. . . Textbooks of philosophy were produced in great numbers, chiefly by the minister-presidents of the colleges, aptly called by one writer 'bearers of the old tradition.' These textbooks were responsible for a major change in the perspective of the study of philosophy. Under their sway, philosophy was considered as a body of material to be learned by the students and recited to the teachers.... [T] here were 'truths' to be presented and illustrated, not the search for and love of wisdom. . .." (Men and Movements in American Philosophy, 80-81).

3. Hall, as the President of Clark University, was the founding president of the American Psychological Association in 1892.

4. Hall, "Philosophy in the United States," 89-91. Other, less polemical surveys from about the same time include: John Dewey's 1886 "Inventory of Philosophy Taught in American Colleges"; and a series of reports by Josiah Royce, Jacob Gould Shurman, Dewey, George Trumbull Ladd, and George Stuart Fullerton about the teaching of ethics at Harvard, Cornell, Michigan, Yale, and Pennsylvania respectively in The Ethical Record for 1889-1890.

5. Coe, "Philosophy in American Colleges," 282-283.

6. Many of the established institutions of higher education also took part in this process of academic growth. At Harvard, for example, Charles William Elliot-a chemist-became president in 1869 and began to rebuild the school in the image of the new university. In a similar fashion, public institutions like Michigan and Wisconsin grew into major universities. See, e.g., William Clyde DeVane, Higher Education in Twentieth-Century America, 34-49.

7. Royce, "The Recent University Movement in America," 144.

8. Angell, "The Old College and the New University," Selected Addresses, $148-149$.

9. Hall, "American Universities and the Training of Teachers," 153. In 1899, Hall spoke lovingly of "the higher plane of purely graduate work" ("Decennial Address," 49). As regards the benefits to the graduate students, the future professors of philosophy, Hall describes the period of doctoral education as transformative: "In beginning more or less independent research like this, our best college graduates are often in a sense suddenly reduced back to infancy and need constant individual help to go alone. ... Having once discovered a fact or made ever so small an original contribution and had the baptism of printer's ink, the novitiate is henceforth a changed man. ... Instead of being a passive recipient, his mind has tasted a free and creative activity which puts him on his mettle like the first taste of blood to a young tiger. $\mathrm{He}$ has learned that achievement and not possession is the end and aim; his mind has been 
brought to a focus in such a way that he now knows what real concentration means as never before" ("Philosophy," 180-182).

10. Harper, The Trend in Higher Education, 152.

11. Creighton, "The Purposes of a Philosophical Association," 224, 226-227.

12. Creighton too had studied in Germany in the late 1880s. In translation: "the time-stealing and strength-sapping academic busy-work" (Ibid., 231).

13. Ibid., 230-232. For Creighton, and the other Idealists at the time, "original work" could be largely historical in nature. As Creighton notes, "[t]o undertake to philosophize without an accurate and sympathetic knowledge of the development of philosophical conceptions is not only vain and fruitless, but it is hopelessly to lose oneself, and to commit intellectual suicide. . . It is not less study of the past that we need, but, doubtless, a more intelligent and discriminating study. And this means a study of historical systems in the light of our own problems" (Ibid., 222-223). Still, as Edward I. Pitts writes, the APA's purposes did not include teaching: "In sum, the goals of the APA as set out by the founders were to turn the profession away from its historic task of the teaching of philosophy and toward a new 'scientific' function, philosophical research. This research was thought to be possible only through cooperative efforts of colleagues who discussed their insights and who helped each other approach the truth more clearly" (The Profession of Philosophy in America, 139-140).

14. Creighton, "The Purposes of a Philosophical Association," 232. He continues that "philosophy does not enjoy the general recognition, even among educated men, that is accorded to many of the other sciences, nor is the philosophical teacher and writer universally conceded to be a specially trained scholar whose opinions in his own field are as much entitled to respect as those of the physicist or biologist in his special domain" (Ibid.).

15. Ibid. Creighton continues that part of the problem of philosophy's low status was the result of its prior role as "the handmaid of theology." In this "subordinate and ancillary position which it so long occupied in this country," philosophy too often degenerated "into empty logomachies and lifeless definitions and justly becomes a byword and reproach among real thinkers" (Ibid., 233).

16. Ibid., 222.

17. Philosophical Review 12, 167.

18. Philosophical Review, 12, 172-173. In the published version of his talk, Royce continues: "The philosopher . . . gains by an avoidance of relation to the visible church, just as a judge gains by declining to be a party man. To the invisible church the philosopher, if loyal to his task, inevitably belongs, whatever be his opinions. And it is to the invisible church of all the faithful his loyalty is due" ("What Should Be the Attitude of Teachers of Philosophy towards Religion?" 285).

19. Journal of Philosophy, Psychology, and Scientific Methods 4, 515-516; Tufts, "Garman as a Teacher," Journal of Philosophy, Psychology, and Scientific Methods 4, 263-267.

20. Journal of Philosophy, Psychology, and Scientific Methods 6, 406; Hudson, "Hegel's Conception of an Introduction to Philosophy."

21. Journal of Philosophy, Psychology, and Scientific Methods 7, 426-428. The first two papers-Edgar L. Hinman, "The Aims of an Introductory Course in Philosophy" and Jay William Hudson, "An Introduction to Philosophy through the Philosophy in History" - were later published, but Bernard C. Ewer's paper, "A Naturalistic Approach to Philosophy," does not appear to have been published. 
22. Presumably, the text in question was Friedrich Paulsen's Einleitung in die Philosophie (1/e, 1892), the third edition of which was translated by Frank Thilly as Introduction to Philosophy (1895).

23. Journal of Philosophy, Psychology, and Scientific Methods 8, 235.

24. Hudson, "The Aims and Methods of Introduction Courses: A Questionnaire," 29,38 .

25. Journal of Philosophy, Psychology, and Scientific Methods 9, 351-353.

26. Philosophical Review 17, 172. Chrysostom's paper was "read by title," meaning that although it was part of the official program it was not actually read at the meeting, perhaps because of time constraints.

27. Philosophical Review 18, 167; Journal of Philosophy, Psychology, and Scientific Methods 6, 45.

28. Philosophical Review 22, 179-180; Journal of Philosophy, Psychology, and Scientific Methods 10, 94.

29. Philosophical Review 25, 172.

30. Philosophical Review 27, 165-169. The discussion sessions were pre-arranged symposia that were intended to focus the thinking of the members of the association on specific philosophical themes. Although some sort of discussion session took place at almost every meeting of the APA through 1920, ongoing dissatisfaction due either to the demands that these symposia made on the membership, or to inadequate execution and consequent lack of success, led to their demise.

31. In addition to Lovejoy, the Committee included: Charles Montague Bakewell, John Elof Boodin, Mary Whiton Calkins, James Edwin Creighton, Durant Drake, William Pepperell Montague, Addison Webster Moore, Ralph Barton Perry, George H. Sabine, Wilmon Henry Sheldon, Edward Gleason Spaulding, and Guy A. Tawney. The report on the meeting notes that "The final draft of the above report was adopted by a majority vote of the Committee, three members being absent, and Professor Creighton dissenting" (Philosophical Review 27, 169n).

32. See also Lovejoy's APA presidential address from the year before: "On Some Conditions for Progress in Philosophical Inquiry"; the responses of Ernest Albee, Charles M. Bakewell, Theodore De Laguna, William Ernest Hocking, and Edmund Howard Hollands: "Progress in Philosophical Inquiry and Mr. Lovejoy's Address"; and Lovejoy's rejoinder: "Progress in Philosophical Inquiry."

33. Philosophical Review 27, 166.

34. Philosophical Review 27, 170-171.

\section{BIBLIOGRAPHY}

Albee, Ernest, Charles M. Bakewell, Theodore De Laguna, William Ernest Hocking, and Edmund Howard Hollands, "Progress in Philosophical Inquiry and Mr. Lovejoy's Presidential Address," Philosophical Review 26:3 (May 1917), 315-338.

[American Philosophical Association] The Meetings of the APA [1903-1926], Journal of Philosophy, Psychology \& Scientific Methods 1-23 (1904-1926).

, The Proceedings of the APA [1902-1926], Philosophical Review 11-35 (1902-1926).

Angell, James Burrill, Selected Addresses (New York: Longmans Green, 1912). 
Blau, Joseph Leon, Men and Movements in American Philosophy (Englewood Cliffs, N.J.: Prentice-Hall, 1952).

Brown, William Adams, "The Future of Philosophy as a University Study," Journal of Philosophy 18:25 (8 December 1921), 673-682.

Coe, George A., "Philosophy in American Colleges," Nation 54 (14 April 1892), 282-283.

Creighton, James Edwin, "The Purposes of a Philosophical Association," Philosophical Review 11:3 (May 1902), 219-237.

DeVane, William Clyde, Higher Education in Twentieth-Century America (Cambridge, Mass.: Harvard University Press, 1965).

Dewey, John, "Inventory of Philosophy Taught in American Colleges," Science 7, Supplement (16 April 1886), 353-355 [Early Works of John Dewey, ed. Jo Ann Boydston, (Carbondale, Ill.: Southern Illinois University Press, 1969-1972), five volumes, 1:116-121].

, "Ethics in the University of Michigan," Ethical Record 2:3 (October 1889), 145-148 [Early Works 3:48-50].

Dodson, George R., "The Function of Philosophy as an Academic Discipline," Journal of Philosophy, Psychology, and Scientific Methods 5:17 (13 August 1908), 454-458.

Flower, Elizabeth, and Murray G. Murphey, A History of Philosophy in America (New York: Putnams, 1977), two volumes.

Fullerton, George Stuart, "Ethical Teaching at the University of Pennsylvania," Ethical Record 2:4 (January 1890), 220-222.

Hall, Granville Stanley, "Philosophy in the United States," Mind 4 (January 1879), 89-105. "American Universities and the Training of Teachers," Forum 17:2 (April 1894), 148-159.

, “Decennial Address," Clark University, 1889-1899: Decennial Celebration

(Worcester: Clark University Press, 1899), 45-69.

, "Philosophy," Clark University, 1889-1899: Decennial Celebration, 177-185.

Harper, William Rainey, The Trend in Higher Education (Chicago: Univ. of Chicago Press, 1905).

Hinman, Edgar L., "The Aims of an Introductory Course in Philosophy," Journal of Philosophy, Psychology, and Scientific Methods 7:21 (13 October 1910), 561-569.

Hudson, Jay William, "Hegel's Conception of an Introduction to Philosophy," Journal of Philosophy, Psychology, and Scientific Methods 6:13 (24 June 1909), 345-353. , "An Introduction to Philosophy through the Philosophy in History," Journal of Philosophy, Psychology, and Scientific Methods 7:21 (13 October 1910), 569-574. , "The Aims and Methods of Introduction Courses: A Questionnaire," Journal of Philosophy, Psychology, and Scientific Methods 9:20 (18 January 1912), 29-39.

Ladd, George Trumbull, "Ethics in Yale University," Ethical Record 2:4 (January 1890), 217-220.

Lovejoy, Arthur Oncken, "On Some Conditions of Progress in Philosophical Inquiry," Philosophical Review 26:2 (March 1917), 123-163.

, "Progress in Philosophical Inquiry," Philosophical Review 26:5 (Sept. 1917), $537-545$.

Montague, William Pepperell, "Philosophy in the College Course," Educational Review 40:5 (December 1910), 488-498.

Paulsen, Friedrich, Introduction to Philosophy, 3/e, tr. Frank Thilly, (New York: Henry Holt, 1895).

Pitts, Edward I., The Profession of Philosophy in America (Dissertation, Penn State Univ., 1979).

Royce, Josiah, "Courses in Ethics in Harvard College," Ethical Record 2:3 (Oct. 1889), $138-143$. 
, "The Recent University Movement in America," Trans. of the Aberdeen Philosophical Society 3 (1900), 131-149.

,"What Should Be the Attitude of Teachers of Philosophy towards Religion?" International Journal of Ethics 13:3 (April 1903), 280-285.

Schneider, Herbert Wallace, A History of American Philosophy (New York: Columbia University Press, 1946).

Schurman, Jacob Gould, "Ethics in Cornell University," Ethical Record 2:3 (Oct. 1889), $143-145$.

Thayer, Horace Standish, Meaning and Action: A Critical History of Pragmatism, rev. ed., (Indianapolis: Hackett, 1981).

Thilly, Frank, "The Teaching of Philosophy," College Teaching: Studies in Methods of Teaching in the College, ed. Paul Klapper, (Yonkers-on-Hudson, N.Y.: World Book, 1920), 302-319.

Tufts, James Hayden, “Garman as a Teacher," Journal of Philosophy Psychology, and Scientific Methods 4:10 (9 May 1907), 263-267.

Wenley, R. M., The Life and Work of George Sylvester Morris: A Chapter in the History of American Thought in the Nineteenth Century (New York: Macmillan, 1917).

[Western Philosophical Association] The Proceedings of the WPA [1901-1904], Philosophical Review 10-13 (1901-1904); [1904-1925], Journal of Philosophy, Psychology \& Scientific Methods 1-22 (1904-1925).

James Campbell, Department of Philosophy, The University of Toledo, Toledo OH 43606; $<$ james.campbell@utoledo.edu>. 